\title{
Anti-anemia Effect of Standardized Extract of Moringa Oleifera Lamk. Leaves on Aniline Induced Rats
}

\author{
Abdul Mun'im ${ }^{1 *}$, Meidi Utami Puteri', Santi Purna Sari ${ }^{3}$, Azizahwati $^{4}$ \\ 'Department of Pharmaceutical Sciences, Laboratory of Pharmacognosy, Faculty of Pharmacy, Universitas Indonesia, Depok, 16424, INDONESIA. \\ ${ }^{3}$ Department of Pharmaceutical Care, Laboratory of Pharmacology-Toxicology, Faculty of Pharmacy, Universitas Indonesia, Depok, 16424, INDONESIA. \\ ${ }^{4}$ Department of Pharmaceutical Care, Laboratory of Pharmaceutical Analysis, Faculty of Pharmacy, Universitas Indonesia, Depok, 16424, INDONESIA.
}

\begin{abstract}
Background: The leaves of Moringa (Moringa oleifera Lamk.) have been empirically used as anti-anemia for pregnant woman. Objectives: In the present study, the effect of ethanolic extract of moringa leaves was evaluated on the hematology parameters (hemoglobin, red blood cell count, hematocrit), on aniline induced white female rats. Materials and Methods: Thirty female rats strain Sprague-Dawley were divided into six groups: normal, anemia and ferrous fumarate group, and three groups of Moringa leaves extract. All groups, except normal group, induced by aniline at dose $0.005 \mathrm{ml} / \mathrm{g}$ bw intraperitonially. On fifth day, normal and anemia groups were given $0.5 \% \mathrm{CMC}$, ferrous fumarate group was given ferrous fumarate orally and three other groups were given Moringa leaves extract at doses 198 mg, 396 mg, and 792 mg/200 g bw until the eleventh day. Results: The results showed that as Moringa leaves extracts increased the level of hemoglobin, red blood cell count, hematocrit, and total iron content in blood. Moreover, Moringa leaves extract at dose $792 \mathrm{mg} / 200 \mathrm{~g}$ bw can
\end{abstract}

improve red blood cell's morphology and increased the level of hemoglobin and red blood cell count significantly $(p<0.05)$. Conclusion: The ethanolic extract of Moringa leaves showed anti-anemia on aniline-induced rats.

Key words: Anemia, Aniline, Erythrocyte, Moringa oleifera L, Total iron.

\section{Correspondence:}

Abdul Mun'im,

Department of Pharmaceutical Sciences,

Laboratory of Pharmacognosy, Faculty of Pharmacy,

Universitas Indonesia,

Depok, 16424, INDONESIA.

Ph no: +6285216104550

Email: munimabdoel@gmail.com

DOI : 10.5530/pj.2016.3.14

\section{INTRODUCTION}

According to data from Center Bureau of Statistic Bureau, Republic of Indonesia in 2007, maternal mortality due to birth in Indonesia reached out to 228 per 100,000 of natality. Based on the data, Maternal Mortality Rate (MMR) in Indonesia is still the highest in Asia and bleeding occupies the highest percentage of maternal mortality (28\%). It is known that anemia and chronic energy deficiency in pregnant women are a major cause of bleeding. ${ }^{1}$

Anemia is a decrease in number of red blood cells (RBCs) or less than the normal quantity of hemoglobin in the blood. WHO recorded an average of $45 \%$ of pregnant women in developing countries are anemic. In Indonesia, there were $63.5 \%$ of pregnant women with anemia. ${ }^{2,3}$ The consequences of anemia in pregnant women include: increased maternal and prenatal mortality and increased numbers of preterm birth and/or low birthweight. ${ }^{4}$ There are iron supplements as a therapeutic agent for anemia but the limitations of bioavailability and side effects of synthetic drugs encourage the development of the use of herbs as an alternative therapy for anemia.

Moringa oleifera Lamk. is the most widely cultivated species of a monogeneric family, the Moringaceae, that is native to the sub-Himalayan tracts of India, Pakistan, Bangladesh and Afghanistan. It is a perennial which for centuries has been advocated for traditional medicinal and industrial uses. All parts of the Moringa tree are edible and have long been consumed by humans. It is known that the Moringa has many benefits based on its nutrition. The ratio of grams per gram, Moringa leaves dry powder contains 25 times more iron than spinach, in which iron is one of the therapeutic agent for anemia. ${ }^{5}$ The aim of this study was to evaluate the anti-anemia effect of Moringa leaves extract anilineinduced rats.

\section{MATERIALS AND METHODS}

\section{Plant materials}

Fresh leaves of Moringa were collected from Botanical Garden of National for Food and Drugs Control Agency Republic of Indonesia, Bogor, East Java, Indonesia. The plant was authenticated by LIPI, Bogor, Indonesia. The specimen was deposited in Herbarium of Laboratory of Pharmacognosy, Faculty of Pharmacy Universitas Indonesia.

\section{Preparation of the extract}

The plant material was air-dried at room temperature. The dried leaves were grounded to powder, then approximately $3 \mathrm{~kg}$ dried of the powder were macerated with $70 \%$ ethanol for $24 \mathrm{~h}$ at room temperature $\left(28^{\circ} \mathrm{C} \pm\right.$ $2^{\circ} \mathrm{C}$ ). Extract was filtered, and the residue was re-macerated two times. The extract was concentrated using rotary vacuum evaporator at a temperature of $50^{\circ} \mathrm{C}$.

\section{Determination of loss on drying}

The extract $(1 \mathrm{~g})$ was heated at a temperature of $105^{\circ} \mathrm{C}$ for $30 \mathrm{~min}$ in oven. at $105^{\circ} \mathrm{C}$ until the weight is stable. Before each weighing, weigh the bottle in the closed position is allowed to cool in a desiccator to room temperature.

\section{Determination of total ash content}

The extract ( $2 \mathrm{~g})$ was weighed carefully and then put in a crucible. Then, the crucible was ignited slowly until charcoal was eliminated, cooled, and had constant weight. Determination levels of acid-insoluble ash: ash obtained in the determination of the total ash content was boiled 
with $25 \mathrm{ml}$ of dilute sulfuric acid for $5 \mathrm{~min}$. Acid insoluble part was collected and filtered through ash-free filter paper and then washed with hot water and was incandescent to keep the weight. Ash content that does not dissolve in acid calculated on the dried material.

\section{Determination of total iron (Fe) content}

The iron content in extract and blood were analysed using atomic absorption spectrophotometry. The sample (extract or blood) was prepared by wet destruction method. Sample was added $10 \mathrm{ml}$ of concentrated $\mathrm{HNO}_{3}$ and has been left for one day. Then the sample was heated until the white smoke appeared then added five drops of $\mathrm{HClO}_{4}$ slowly. Sample solution has been allowed to cool and then filtered using filter paper and was diluted into a $50 \mathrm{~mL}$ volumetric flask with distilled water. The absorbance was then measure using spectrophotometer.

\section{Phytochemical screening of the extracts}

Phytochemical constituent such as alkaloid, flavonoid, terpene, saponin, glycoside and anthraquinone in the extracts was performed by using standard analytical procedures with slight modification. ${ }^{6}$ The analysis also was performed with TLC using specific sprayreagents. Spray reagents used were Dragendorff for alkaloid; $\mathrm{AlCl}_{3}$ for flavonoid; and $\mathrm{FeCl}_{3}$ for tannin.

\section{Experimental design}

The experiments were carried out in 30 female albino rats of the species Ratus norvegicus, Sprague Dawley Strain, weighing 150-200 g. The study was approved by the Institutional Animal Ethical Committee (Registration no.634/02/a/CPCSEA). The animals were acclimatized for 2 week under laboratory conditions. Completely randomized design (CRD) is used in this study. The rats were divided into six groups with five animals in each groups $(\mathrm{n}=5)$ as follows:

- Group I (normal group)-received 0.5\% CMC $3 \mathrm{ml} / 200 \mathrm{~g}$ bw/day p.o. for 6 days.

- Group II(negative control)-received 0, 5\% CMC 3 ml/200 g bw/day p.o. for 6 days.

- Group III (positive control)-received Ferro Fumaras Suspension $175,5 \mathrm{mg} / 200 \mathrm{~g}$ bw/day p.o. for 6 days.

- $\quad$ Treatment group IV received Moringa leaves extract at doses 198 $\mathrm{mg} / 200 \mathrm{~g}$ bw/day p.o. for 6 days

- $\quad$ Treatment group V received Moring leaves extract at doses 396 $\mathrm{mg} / 200 \mathrm{~g}$ bw/day p.o. for 6 days

- Treatment group VI-received Moringa leaves extract at doses 792 $\mathrm{mg} / 200 \mathrm{~g}$ bw/day p.o. for 6 days.

\section{Induction of anemia}

The experiment was performed using aniline (Wako, Japan) for inducing anemia. Aniline suspension was given by injection intraperitoneally $(0.003 \mathrm{ml} / \mathrm{gbw} /$ day $)$. All the animals, except the normal group were treated with the injection of aniline for 2 days, along with the normal diet. On the fifth day, blood of animals were collected for evaluation. Then normal and negative control were given 0.5\% CMC, positive control was given ferrous fumarate and three other groups were given Moringa leaves extract at doses $198 \mathrm{mg}, 396 \mathrm{mg}$, and $792 \mathrm{mg} / 200 \mathrm{~g} \mathrm{bw} /$ day until the eleventh day. The blood was collected from the rat's eye.

\section{Assessment parameters}

In this study, three parameter of anemia were observed. There are the shape of red blood cells used light microscope, the hematology examination (hemoglobin levels, the number of erythrocytes and hematocrit levels) using hematology analyzer, and the calculation of total iron (Fe) concentration in blood using atomic absorption spectrophotometer.

\section{Statistical Analysis}

The data were presented in terms of mean and standard deviation. The statistical significance was evaluated by ANOVA and Mann-Whitney. Differences at pvalue of less than 0.05 was considered statistically significant.

\section{RESULTS AND DISCUSSION}

The ethanol extract of Moringa leaf extract obtained in the form of thick and sticky, brown, aromatic odor, sour taste, and have solid extract in the amount of $27.32 \%$. Screening of the chemical constituent of Moringa leaf extract obtained that extract contains of flavonoids, alkaloids, saponins, tannins, and glycosides. The Moringa leaves contained of flavonoid, alkaloid, phenol, steroid and glycosides. This results is similar with previous study.? The results indicated that the determination of non-specific parameters showed that extract of Moringa leaves have averaged $21.18 \%$ percent drying, total ash content of $1.70 \%$, and acid insoluble ash content of $0.28 \%$. Total iron content in Moringa extract of the averageis $19.38 \mathrm{mg} / \mathrm{kg}$ of extract.

Hemolytic anemia with aniline as an induction model is chosen because it is easier and cheaper than the other induction model, such as genetical induction model or using the other medicines. ${ }^{8}$ Anemia occurred accordance with the effects caused by aniline induction, which came from methemoglobinemia and hemolytic anemia. They can be occurred because an active metabolite from aniline which is phenylhydroxylamine oxidized oxyhemoglobin to methemoglobin and hydrogen peroxide $\left(\mathrm{H}_{2} \mathrm{O}_{2}\right) \cdot \mathrm{H}_{2} \mathrm{O}_{2}$ could cause oxidation of $\mathrm{SH}$ groups that are important in protein. Beside that, it also causes the lipid peroxidation on the red blood cells's membrane which lead the membrane to lysis. ${ }^{8-10}$

This study used six groups of female rats which are consisted of five rats per group. The dose variation which is used in this study is aimed to know which dose of Moringa leaves that has optimal effect. In this study, three parameters of anemia are observed. There areobservation of the shape of red blood cells, the calculation of the blood hematology (hemoglobin levels, the numbers of erythrocytes, and hematocrit levels), and the calculation of total iron $(\mathrm{Fe})$ concentrationin blood.

The examination with hematology analyzer sometimes could not reflect the real situation therefore the confirmation of the red blood cells's shape is needed for cross checking. The red blood cells's shape is observed by using light microscope. This is a qualitative observation, which only observes the shape of the red blood cells and compares the preparations of peripheral blood smears between the treatment groups. The observation was done on the $11^{\text {th }}$ day after treatment of the Moringa leaves extract.

Figure 1 shows that the red blood cells'shape on anemia control group and dose 1 group has not recovered yet, because the size was smaller than the normal group. On the ferrous fumarate group and the group of dose 3 showed that the red blood cells'shape has already recovered to be normal. Meanwhile, the red blood cell's shape group of dose 2 has not completely recovered. Based on these observations, researcher conclude that on the anemia control group and the group of dose 1, it had still mycrocitic anemia where the shape of red blood cells are happened to be smaller than normal. Therefore, on the ferrous fumarate group and the dose 3 group show that there was an influence ingestion of the ferrous fumarate suspension and Moringa leaves extract on the red blood cells'shape. It can be seen from the shape which is back to normal. The group of dose 2 of Moringa leaves extract recover the shape of red blood cell, but it is not significant.

The second and third parametersare the observation of hematology value and total iron content. Detailed results can be seen at Table 1 . 


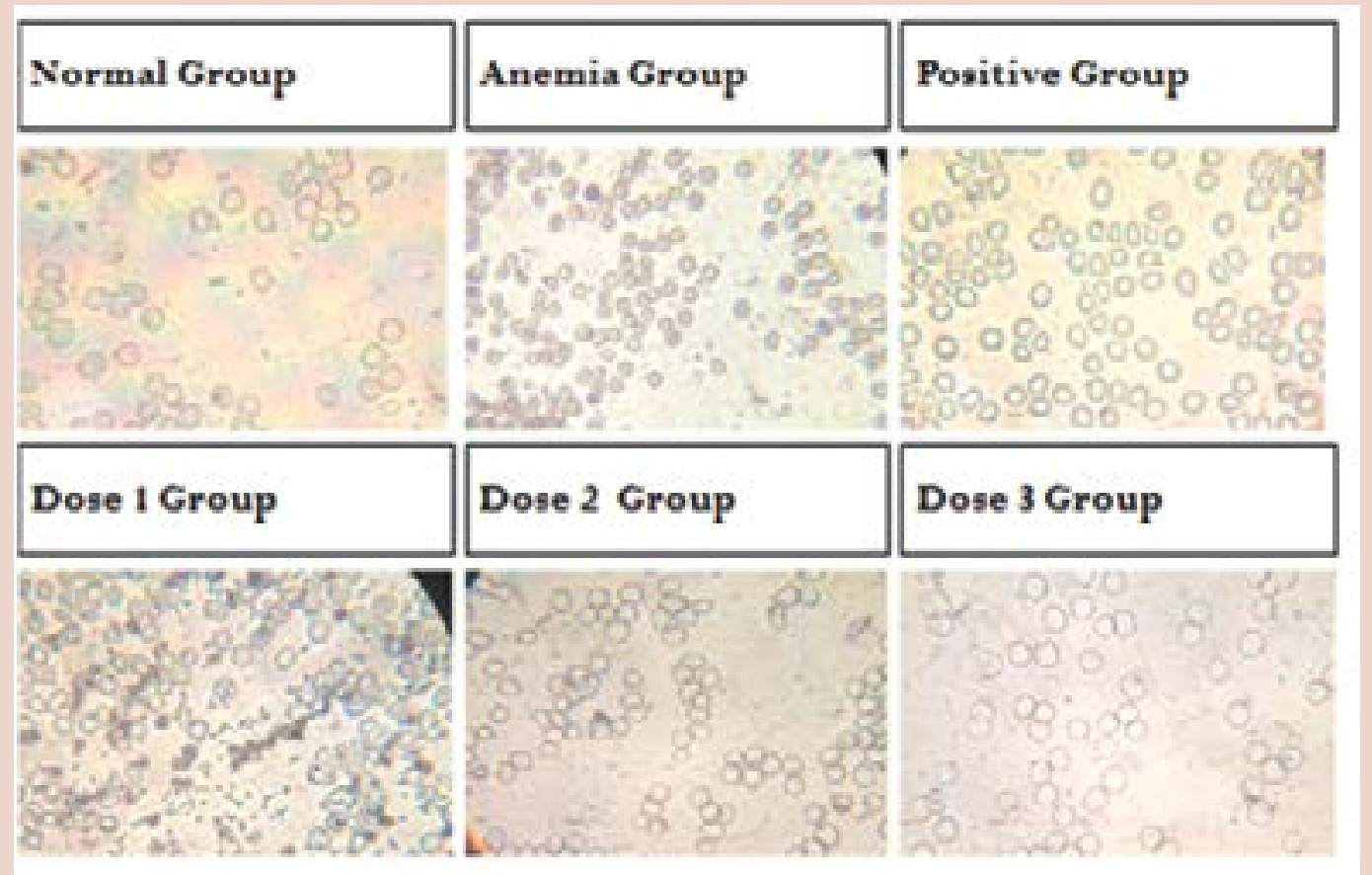

Figure 1: Peripheral blood smears of the white female rats after extract administration.

Table 1: Increase in the percentage of hemoglobin levels, erythrocyte, hematocrit and average total iron content in female rats after extract administration

\begin{tabular}{ccccc}
\hline \multirow{2}{*}{ Group } & \multicolumn{4}{c}{ Percentage increase (\%) } \\
\cline { 2 - 5 } & Erythrocyte & Hemoglobin & Hematocrit & Total Iron \\
\hline Normal & 4.42 & 1.98 & 4.14 & 2.39 \\
Anemia & 8.48 & 8.78 & 18.75 & 33.43 \\
Positive & 28.25 & 26.67 & 50.08 & 52.92 \\
Dose 1 & 30.63 & 25.26 & 46.35 & 40.04 \\
Dose 2 & 33.83 & 36.13 & 53.82 & 26.69 \\
Dose 3 & 40.32 & 34.97 & 60.38 & 59.51 \\
\hline
\end{tabular}

The table shows the increasing percentage of hematology parameter and total iron content in blood. The treatment of ferrous fumarate increased erythrocyte, hematocrit and total iron.

The increase anemia parametersin positive group is caused by ferrous iron which is presented in ferrous fumarate. It was absorbed efficiently by the rats and lead an increasing of red blood cells production. The iron content in the Moringa leaves acts as main nutrient in hematopoiesis process in the spinal cord, because Moringa leaves were reported iron-rich. ${ }^{11}$ Beside that, the protein and amino acids content in Moringa leaves are also act as hematopoietic growth factor. The leaves reported high content of protein and amino acids. ${ }^{12-13}$ It plays vital role in managing proliferation and blood cells differentiation. Vitamin $\mathrm{C}$ content in Moringa leaves extract also increase iron absorption in body. ${ }^{14}$ In addition to the dose-treatment groups, hemoglobin and erythrocytes levels are also increased in anemia control group which did not get Moringa leaves extract treatment. The increased is due to the normal process of the body, which would boost the eritopoesis process (the formation and maturation of erythrocytes) that happen when body cells are deprived of oxygen. ${ }^{15}$

\section{CONCLUSION}

The results showed that as the dose of Moringa leaves increasing, the level of hemoglobin, erythrocyte, hematocrit, and total iron content in blood of rats are also increased. Moreover, Moringa leaves extract at dose $792 \mathrm{mg} / 200 \mathrm{~g}$ bw/day can improve erythrocyte's morphology and increase the level of hemoglobin and erythrocyte of rats significantly $(\mathrm{p}<0,05)$.

\section{ACKNOWLEDGEMENTS}

This study was supported financially by the Directorate General of Higher Education, Ministry of National Education Republic of Indonesia, via Hibah BOPTN Desentralisasi 2013.

\section{CONFLICT OF INTEREST}

All co-authors have seen and agree with the contents of the manuscript and there is no financial interest to report. We certify that the submission is original work and is not under review at any other publication.

\section{ABBREVIATION USED}

RBCs: red blood cells; CMC: Carboxymethyl cellulose; CRD: Completely randomized design.

\section{REFERENCES}

1. Center Bureau for Statistic Republic of Indonesia. Demography and Health Surveyin Indonesia: supporting document. 2008.

2. Mason J, Rivers J, Helwig C. Recent trends in malnutrition in developing regions: Vitamin A deficiencies, anemia, iodine deficiency, and child underweight. Food Nutr Bull. 2005;26(1):57-162.

3. Saifudin. Buku Acuan Nasional Pelayanan Kesehatan Maternal dan Neonatal. Ed I, Yayasan Bina Pustaka, Jakarta. 2006.

4. Fahey JW. Moringa oleifera: A Review of the Medical Evidence for Its Nutritional, Therapeutic, and Prophylactic Properties. Part 1. Trees Life J. 2005;1:5. 
5. Kasolo JN, Bimenya GS, Ojok L, Ogwal-Okeng, JW. Sub-acute toxicity evaluation of Moringa oleifera aqueous and ethanol extracts in Swiss Albino Rats. Inter J Med Plant Res. 2012;1:75-81.

6. Mun'im A, Katrin, Azizahwati, Andriani A, Mahmudah KF, Mashita M. Screening of $\alpha$-glucosidase inhibitory activity of some Indonesian medicinal plants. Inter J Med Arom Plant. 2013;3(2):144-50.

7. Anwar F, Latif S, Asraf M, Gilani AH. Moringa oleifera: A food plant with multiple medicinal uses. Phytotherapy Research. 2007;21(1):17-25.

8. Ciccoli L, Ferrali M, Rossi V, Signorini C, Alessandrini C, Comporti M. Hemolytic drugs aniline and dapsone induce iron release in erythrocyte and increase the free iron pool in spleen and liver. Toxicol Letter. 1999:110(1-2):57-68.

9. Umbreit J. Methemoglobin-it's not just blue: a concise review. Amer J Hematol. 2007;83(2):138-44.

10. Murray R, Granner DK, Mayes PA Rodwell WW, eds. Harper's Biochemistry, $25^{\text {th }}$ ed London, Prentice Hall International Inc. 2000.
11. Barminas JT, Charles M, Emmanuel D. Minreal composition of non-conventional leafy vegetables. Plants Food Hum Nutr. 1998;53(1):29-36.

12. Afuang W, Siddhuraju $P$, Becker K. Comparative nutritional evaluation of raw, methanol extratcted residue and methanol extracts of moringa (Moringa oleifera Lam.) leaves on growth performance and feed utilization in Nile tilapia (Oreochromis niloticus L.). Aquacul Res. 2003;34(13):1147-59.

13. Makkar HPS, Becker K. Nutritional value and antinutritional components of whole and ethanol extracted Moringa oleifera leaves. Animal Feed Sci Technol. 1996;63(1):211-28.

14. Katzung BG, Masters SB, Trevor AJ. Basic and Clinical Pharmacology, $10^{\text {th }}$ ed, San Fransisco: Mc.Graw Hill. 2006; 489-93.

15. Sherwood L. Fisiologi manusia dari sel ke sistem edisi edisi 2. Indonesian translation fromHuman physiology:from Cells to system by Brahmm U.P. Jakarta: EGC. 2001.

\section{PICTORIAL ABSTRACT}

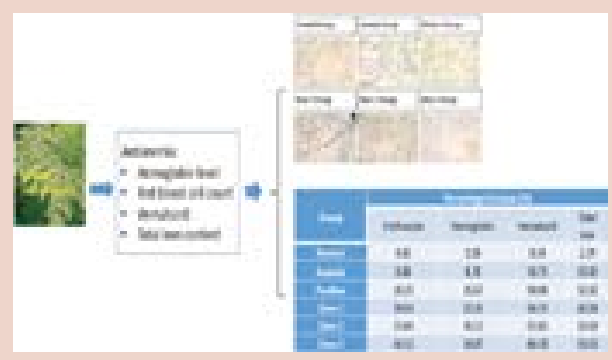

\section{SUMMARY}

- Moringa leaves extract significantly increased the level of haemoglobin.

- Moringa leaves extract increased the level of red blood cell count.

- Moringa leaves extract increased the level of total iron content in the blood.

\section{ABOUT AUTHORS}

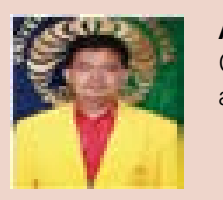

Abdul Mun'im: Completed his PhD degree at Institute of Applied Biochemistry, University of Tsukuba, Japan. Currently, he focused his research on Indonesia's traditional medicinal plants for anti-metabolic syndrome, such anti-diabetes, anti-dyslipidaemia and anti-hypertension, via inhibition of angiotensin converting enzyme activity.

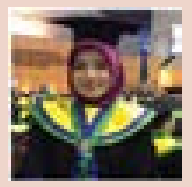

Meidi Utami Puteri: Finished her bachelor in pharmacy, at Faculty of Pharmacy, Universitas Indonesia. Now sheis a master student at the Faculty of Medicine, University of Tsukuba (Japan). Her master research focused on experimental pathology.

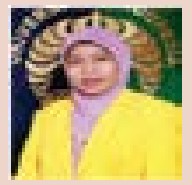

Santi Purna Sari: Finished her master program at Faculty of Pharmacy, University of Gadjah Mada, Yogyakarta, Indonesia. Her research in master program wasabout Pharmacokinetic and pharmacodynamics interaction between herbal products with conventionaldrugs. She focused her research on pharmacologicalactivity and toxicology of natural productsin vitro and in vivo.

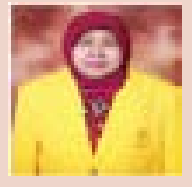

Azizahwati: Finished her master at Faculty of Medicine, Universitas Indonesia. She is Chairman of Laboratory of Pharmaceutical Analysis. Currently, she focused her research on organic sulfur compound from Indonesia's Traditional Medicinal Plants, and their hepatoprotective activities. 